\title{
The Effect of Implementation Quality System on the Quality Culture of Farmers (Case Study on Edamame Production Industries)
}

Sri Sundari

State Polytechnic of Jember; sundari_polije@yahoo.co.id

Ridwan Iskandar

State Polytechnic of Jember; ridwan.iskandar@yahoo.com

\section{Ernie Tisnawati Sule}

Department of Management Padjajaran University

\section{Doi:10.5901/mjss.2015.v6n5s5p209}

\section{Abstract}

In conjunction with the quality of raw material suppliers, farmers need to be developed to implement quality standards internationally recognized so as to form a high-quality cultural behavior in production activities. The purpose of this study was to determine the effect of the application of HACCP management and quality management on quality culture through the performance of farmer groups. The study was conducted on edamame soybean production centers in Jember, Lumajang and Bondowoso. The study can be used as input for the management company to assess the implementation of the core variables of research that has been conducted in order to improve the performance of farmer groups and cultural quality of the plasma, and then as input for the plasma to determine production strategies in order to produce a quality product. Sampling methods for farmers is done by using snowball sampling. To examine the relationship between variables observed with latent variables, use the software SEM. The results of the analysis and testing of suitability models were then compared with the size of the goodness of fit. The results showed that the conceptual model of structural equation models have met the eligibility (fit), this result indicates that the model fits the empirical conditions. Theoretical research model is an adaptation of the concept of quality management system. According to our model, HACCP Management and Quality Management System has positive influence on the Quality Culture of Edamame Farmers through Group Performance. Partially, quality management culture has positive effect on the quality of edamame farmers.

Keywords: Edamame soy, HACCP, quality, farmer groups, culture.

\section{Introduction}

Quality of product can be only obtained by applying the concept of quality control and quality assurance which will make the company achieve a culture of quality as the main target. At the national level, governments need to continue to try to achieve a high level of quality culture by means of spur various production centers to be able to produce quality products. One sector that continues to be driven is the agricultural sector, which sought its products can compete in the global market. Towards the era of globalization in 2020 and in order to revitalize the agricultural sector, the development of the agricultural sector will be increasingly important, given its strategic role in the economy of Indonesia, both as a provider of industrial raw materials, sources of foreign exchange earnings export, absorbing the labor and in maintaining the sustainability of natural resources. One of the agri-food products that many consumers demand is edamame soybeans, namely soybean harvested at the peak of maturation (age 57 days) just before reaching the hardening time, which is a commodity that is exported, especially to Japan. Exports of new soybean seed began to grow since 1990, in a relatively small amount. Exports of fresh young soybean in the form clots (frozen soybean) is still open particularly clot edamame soybeans to Japan and other countries. In Jember since 1992 has been successfully cultivated soybean edamame, besides superior in quality and size, protein content is also higher than ordinary soy. Japanese market today require a supply of 100 thousand tons per year, while Indonesia only able to export edamame to Japan as much as 3,000 tons per year.

(http://myforesthouse.blogspot.com/2012/11/kedelai-jepang-menantang-ekspor.html). 
In order to fill the edamame market opportunities, efforts are needed to increase the quantity and quality of production in order to increase the supply to the export market. This, among others, can be reached by developing farmers who supply raw materials exports edamame, and is also able to produce edamame with international quality standards on an ongoing basis. In relation as a supplier of qualified raw material, the farmers need to be directed to implement quality standards internationally recognized so as to form a high quality cultural behavior in production activities. Therefore we need a full investigation of the quality culture in the farmers who supply raw materials, so it can be seen efforts to maintain and improve the quality of cultural behavior.

Implementation of quality management system ISO 9001: 2000 at the level of cultivation edamame shows the level of preparedness that fall into the category of Medium (Fair). This suggests that edamame farmers have implemented some elements according to the quality management system standard ISO 9001: 2000, but there is still an important part of the quality system which is not in accordance with such standards, or even none at all. Thus it can be said that the farmers edamame has reached the quality culture in the medium category (fair) (Iskandar, R. et al., 2008).

An explanation of the current edamame farmers in terms of achievement of quality culture based on the level of implementation of the quality management system is as follows (Iskandar, R. et al., 2008):

(a). Clause Quality Management System has a higher value ratio compared to other clauses, so that it occupies top priority clause to be implemented. This shows that the whole activity will rely on clause Quality Management System considering the whole activity of quality care function properly if its quality system has been very clear. (b) Clause Measurement, Analysis and Improvement the most recent was ranked in terms of importance. However it must be remembered that the lowest ranked does not mean unimportant in the overall quality system ISO 9001: 2000, where the implementation of this clause is also an important clause because the activity measurement, analysis and improvement is very necessary as feedback.

(c) Edamame farmers has two clauses with categories Weak, that clause 3 (Resource Management) and clause 5 (Measurement, Analysis and Improvement).

Just as in other agricultural commodities, where the farmer as the spearhead of edamame production not be separated from the farmer groups.. Development of farmer groups directed at improving the ability of farmers' groups in carrying out its functions, namely to increase the ability of the members to develop agribusiness. Furthermore, the Ministry of Agriculture (2007) suggested that the increased capacity of farmer groups is so that the group can serve as learning class, cooperation and production units vehicle, facilities and infrastructure provider, processing and marketing units and also unit support services to become strong farmers' organizations and independent.

The quality system is a set of standards to ensure an activity produces quality output continuously, in this case the quality system in question is HACCP and ISO. HACCP (Hazard Analysis and Critical Control Point) is a tool to assess hazards and establish control systems that focus on prevention rather than relying mostly testing the final product (USDA, 1999). The ISO quality management is a management system for directing and controlling the quality of an organization, through the establishment of policy and quality objectives as well as control to achieve certain goals.

Development and continuous improvement of the quality system at a time will be able to reach a point that is capable of improving the performance of the group, which is a condition that results in an environment that is conducive to the establishment and continuous quality improvement.

The achievement of the group's performance will affect the quality culture group members (farmers), the better performance level of the cultural group, the better the quality of the farmers. Many organizations assume that the performance has been good, but did not consider the quality of members of cultural factors in the quality of performance measurement. Therefore need to be investigated the relationship between the performance of the group with a quality culture of farmers, particularly in the industrial environment of edamame.

Based on the description above, can be prepared following hypotheses: (1) HACCP management has a direct and positive relationship with the farmer group performance; (2) Quality management has a direct and positive relationship with the farmer group performance; (3) Quality management has a direct and positive relationship with the quality of farmers' culture; (4) The group's performance has a direct and positive correlation with quality culture farmers

In general, the study aimed to determine the factors that affect the successful implementation of quality culture farmers. The experiment was conducted on edamame soybean production centers in Jember, Lumajang and Bondowoso East Java province involving edamame soybean farmers. 


\section{Literature Review}

\subsection{Quality System}

Hazard Analysis and Critical Control Point (HACCP) is a system that identifies specific hazards that may arise and how to prevent it to control those hazards. According to the National Standardization Agency (1998), HACCP is a tool to assess hazards and establish control systems that focus on prevention rather than relying on end-product testing. Use of HACCP is to prevent the withdrawal of food, improving food safety assurance, improvement and processing unit (production), preventing the loss of customers, increasing consumer confidence, and prevent wastage costs. HACCP can be applied to the entire food chain from primary products to the final consumer and implementation should be guided by scientific evidence of risks to human health. HACCP is a very good food safety system in controlling the risk of food hazards in the food SMEs organization (Zulfifly, Muhammad Izzat;, et. al., 2010).

Son et al. (2012) suggested that for the future the need for studies on the application of HACCP at the farm level. This will optimize the application of quality culture at the farm level. Therefore, as an initial effort, this study will look into the matter although the extent of examining the effect of the application of HACCP at the core level of the plasma level of quality culture.

Kolarik (1995) suggested that the definition of quality is quite good variety of practitioners and scholars presented. In this study, the concept of quality refers to the quality management system ISO 9001: 2008, the traits and characteristics of the products/services capable of satisfying the needs expressed.

To obtain top quality products, companies need to implement the concept of quality control and quality assurance. Quality control in principle implies that each product must be manufactured in accordance with the request, where the approach is done through the implementation of Total Quality Management (TQM) is an approach that maximizes employee participation and competitiveness of the organization through continuous improvement on the products $I$ services, human, processes, and the environment. According to Cole et al. (1993), participation can be defined as employee involvement in decision-making, in which participation must have four characteristics, namely: formal, direct, local, and open. The effective Quality Assurance includes three things, namely: (1) an effective Quality Management System, (2) Periodic checks on the implementation of the system to ensure its effectiveness, and (3) periodic review of the system on an ongoing basis. Reflects the recognition in the form of a certificate of ISO quality assurance in all parts of the company (Munro-Faure, 1992). In the plasma core concepts, quality assurance including the plasma level. If the quality assurance have been entrenched it will establish a culture of quality, therefore, this study intends to verify it.

Total Quality Management (TQM) have direct and significant impact to increase or improve the performance of SAIPA Group Companies (Tabe, Hamid Reza, et.al., 2013).

\subsection{Group Performance}

In an effort to improve the development of food security, farmers' groups have a very large role in supporting various programs due to farmer groups is basically the main actors of development of food security. Farmers groups are very effective as a means of learning, working, and capital accumulation in the development of farming groups. According to the Ministry of Agriculture (2007), institutional empowerment of farming as a business unit in the smallest farmers groups in need of repair and coaching both technical and institutional management. Revitalization of Agricultural Extension has been announced by the government in order to improve the welfare of farmers who followed up with the implementation of Farmer Empowerment through Agricultural Technology and Information (P3TIP) from 2006 to 2011.

Farmers Group Functions include three things, namely (a). Classroom Learning, ie teaching and learning container members in order to improve the knowledge, skills and attitudes; (b). Rides Cooperation, which is a place to strengthen cooperation amongst member farmers and between farmers' groups as well as with other parties; and (c). Production units, namely farming carried out by each member, as a whole should be seen as an entity that can be developed to achieve economies of scale.

\subsection{Quality Culture}

To understand the meaning of quality culture should be understood first roots of the culture of quality that organizational culture, because culture is a subset of the quality of the organization's culture. According to Robbins (2001), organizational culture is a system of shared meaning to the primary values are shared and respected organizations, which function creates a clear distinction between one organization to another, creating a sense of identity for the 
members of the organization, facilitate the emergence of a collective commitment to organization, increase the stability of the social system, as well as creating meaning makers and control mechanisms that guide the shaping attitudes and behavior of the members of the organization.

According Goetsch D.L dan Davis D.L (2002), quality culture is a system of organizational values which produce an environment that is conducive to continuous quality improvement. Quality culture consists of philosophy, beliefs, attitudes, norms, traditions, procedures, and expectations of quality improvement.

Quality culture consists of the Organization's Mission and Relationship to Nature, The Nature of Reality and Truth, The Nature of Human Nature and Relationship, The Nature of Time and Space (Kujala and Ullrank, 2004).

Total Quality Management (TQM) is a manifestation of culture, attitude and organization of a corporation serving customers in the form of products and services that can meet their needs. The corporate culture is in dire need of quality in all aspects of operations, processes are carried out correctly, and defects and waste are eliminated from the operating system. To succeed in the implementation of TQM, it is necessary to 8 primary key should be the concentration of an organization, namely: (1) Ethics, (2) Integrity, (3) Trust, (4) Training, (5) Teamwork, (6) Leadership, (7) Recognition, (8) Communication.

\section{Research Method}

This research was conducted in Jember, Lumajang and Bondowoso on East Java province due to that the site is the largest producer in Indonesia edamame soybean. Samples were edamame soybean farmers are taken with snowball sampling method. Snowball sampling is a sampling technique of the population who do not clear the existence of its members and was not sure how to find the number by one sample, then the sample is searched (extracted) information on the whereabouts of the samples the other, continue to do so in a chain (Amirin, Tatang M, 2011).

Based on the problems that have been formulated, the proposed conceptual model of research as in Figure 1.

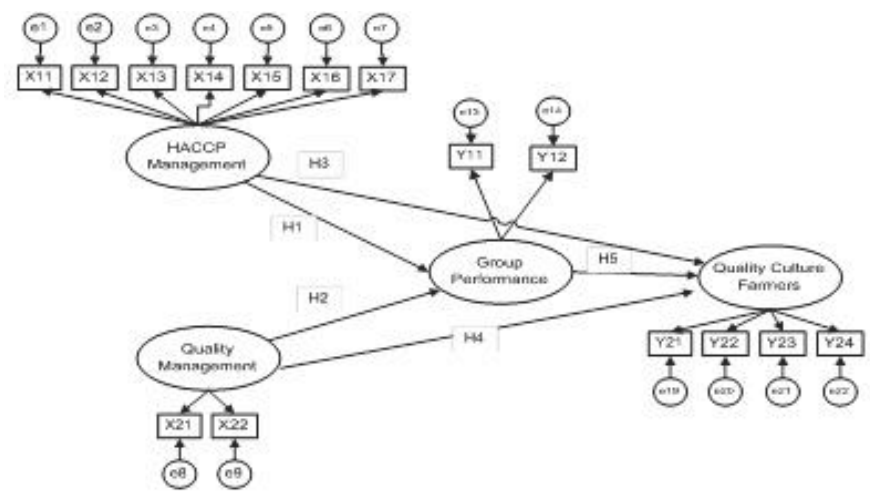

Figure 1. Conceptual Model Research

For data analysis and model testing and inferential analysis was used to examine the relationship between variables observed with latent variables used software Structure Equation Modeling (SEM).

\section{Results and Discussion}

\subsection{The Identity of Respondents}

Survey respondents amounted to 372 people. 372 figure stated is sufficient based on the facts on the ground that the respondent has been unable to show again the other respondents, in addition to the data and information required to be sufficient. Includes elementary education level of respondents (13\%), secondary (40\%), high school (45\%) and university $(2 \%)$, by gender Men (90\%) and a woman (10\%). Age of respondents most of productive age/under age $40(60 \%)$ and the rest over 40 years. 


\subsection{Normality Test}

First tested the normality of data. Data considered normal if c.r multivariate (critical ratio) has a value of $-2.58<c . r<2.58$. Normality test results indicate the data has a c.r multivariate value of $1,852<2.58$ means the normal distribution.

\subsection{Conformance Test of Model}

The results of the model fit tests in this study are complete can be seen in Figure 2 .

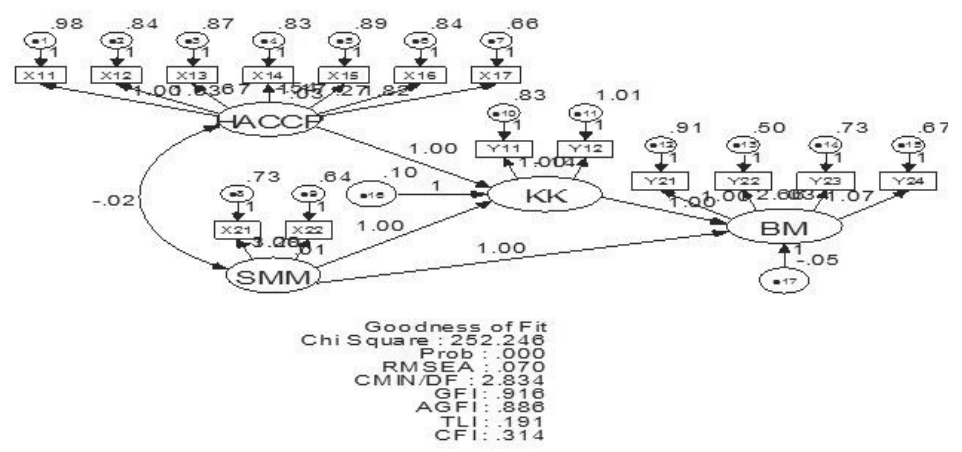

Figure 2. Conformance Test of Model

Information:

HACCP = Hazard Analysis and Critical Control Point

$\mathrm{SMM}=$ Sistem Manajemen Mutu (Quality Management System)

KK = Kinerja Kelompok (Group Performance)

$\mathrm{BM}=$ Budaya Mutu (Quality Culture) Table 1.

The results of the model fit tests using the chi-square, cmin/df, GFI, AGFI, RMSEA, TLI and CFI summarized in

Table 1. Results of Measurement Model Goodness of Fit

\begin{tabular}{lccc}
\hline Index & Cut Off Value & The Results & Evaluation \\
\hline chi-square & Close to 0 & 252.246 & Bad \\
Probability & $\geq 0.05$ & 0.000 & Bad \\
cmin/df & $\leq 2.00$ & 2.834 & Bad \\
GFI & $\geq 0.90$ & 0.916 & Good \\
RMSEA & $\leq 0.08$ & 0.070 & Good \\
AGFI & $\geq 0.90$ & 0.886 & Bad \\
TLI & $\geq 0.90$ & 0.191 & Bad \\
CFI & $\geq 0.90$ & 0.314 & Bad \\
\hline
\end{tabular}

Table 3 shows that the model does not fit the planned marginally after tested for compliance, most of the value compared with the reference value (cut off value) give poor results (bad). The model is then modified to follow Modification Indices (Table 2) by connecting the measurement error 4 to 7, measurement error 2 to 6 , measurement error 4 to 14 , measurement error 8 to 12, and so on with consideration of the highest values.

The results of the model fit tests after modification using the chi-square, cmin/df, GFI, AGFI, RMSEA, TLI and CFI summarized in Table 3. (1) HACCP management variables significantly affect the performance of the group; (2) Variable quality management system significantly affects the performance of the group; (3) Variables significantly affect group performance quality culture; (4) Variable quality management system does not significantly affect the quality culture t-test for significance is smaller than the probability of $>0.05$. 
Tabel 2. Modification Indices

\begin{tabular}{|c|c|c|c|c|c|}
\hline Covariances: & M.I. & Par Change & Covariances: & M.I. & Par Change \\
\hline e8<-------> e14 & 4.361 & -0.080 & e5<-------> e10 & 6.079 & 0.112 \\
\hline e8<--------> e12 & 11.428 & -0.145 & e5 <---------> e6 & 7.125 & 0.121 \\
\hline e11 <--------> e8 & 4.998 & 0.100 & e4 <--------> e14 & 14.340 & 0.154 \\
\hline e10<------> e14 & 5.759 & 0.098 & e4 <-------> e12 & 4.748 & 0.100 \\
\hline e10<--------> e9 & 4.952 & 0.089 & e4 <---------> e8 & 9.006 & -0.122 \\
\hline e10<-------> e8 & 5.799 & 0.099 & e4 <--------> e7 & 15.444 & 0.157 \\
\hline e7 <-------> e14 & 9.714 & 0.117 & e4 <--------> e5 & 5.632 & -0.108 \\
\hline e7 <---------> e8 & 6.420 & -0.095 & e2 <--------> e15 & 6.326 & 0.100 \\
\hline e6 <------> HACCP & 6.662 & 0.025 & e2 <---------> e6 & 15.131 & 0.170 \\
\hline e6<-------> e12 & 4.023 & 0.092 & e1 <-------> e9 & 6.763 & -0.112 \\
\hline e5<--------> e15 & 8.566 & -0.120 & e1 <--------> e10 & 6.177 & -0.118 \\
\hline e5 <--------> e12 & 8.641 & -0.140 & e1 <--------> e2 & 7.096 & 0.127 \\
\hline e5 <-------->> e8 & 7.206 & 0.114 & & & \\
\hline
\end{tabular}

Table 3. Results of Goodness of Fit Model Measurements After Modification

\begin{tabular}{lccc}
\hline Index & Cut Off Value & The Results & Evaluation \\
\hline chi-square & Approach 0 & 71.761 & Marginal \\
Probability & $\geq 0.05$ & 0.236 & Good \\
cmin/df & $\leq 2.00$ & 1.121 & Good \\
GFI & $\geq 0.90$ & 0.975 & Good \\
RMSEA & $\leq 0.08$ & 0.018 & Good \\
AGFI & $\geq 0.90$ & 0.953 & Good \\
TLI & $\geq 0.90$ & 0.947 & Good \\
CFI & $\geq 0.90$ & 0.967 & Good \\
\hline
\end{tabular}

\subsection{Direct Effect, Indirect Effects and Total Effects Variables}

The influence amount of each latent variable directly (standardized direct effect) or indirectly (standardized indirect effect) and the total effect is summarized in Table 4.

Table 4. Effect of Direct, Indirect and Total Effects Variables

\begin{tabular}{lccc}
\hline Variabel & Direct Effect & Indirect Effect & Total Effect \\
\hline HACCP Management $\rightarrow$ Group Performance & 0.755 & 0.000 & 0.755 \\
Quality Management $\rightarrow$ Group Performance & 0.452 & 0.000 & 0.452 \\
Group Performance $\rightarrow$ Plasma Quality Culture & 1.825 & 0.000 & 1.825 \\
Quality Management $\rightarrow$ Plasma Quality Culture & 0.824 & 0.824 & 1.648 \\
\hline
\end{tabular}

The influence amount of each latent variable directly (standardized direct effect) or indirectly (standardized indirect effect) as well as the total effect (standardized total effect) is described as follows: (1) Variable HACCP management has a direct impact on group performance variables for 0.755 ; (2) Variable Quality Management has a direct impact on group performance variables for 0.452; (3) Variable Group Performance has a direct influence on variables Quality Culture for 1.825; (4) Variable Quality Management has a direct influence on variables Quality Culture for 0.824.

\section{Conclusion}

Based on the research model, HACCP Management and Quality Management Systems gives positive effect on edamame farmers group performance. Directly, Quality Management System has a positive influence on the Quality Culture of farmers. Performance Group has a direct influence on the Quality Culture of farmers.

Company's core needs to improve the understanding and application of HACCP management and quality management system at the level of edamame farmers through appropriate training. Development of edamame farmers aims mainly to always produce quality products consistently needs to be done through an increase in the role of farmer 
groups as creative agents of change for its members by promoting the principles of mutual respect, openness, participation, and partnership. In addition, the company's core needs to be more intensive in monitoring and improving the quality of cultural achievement edamame farmers through increased communication and understanding of the aspirations of farmers.

\section{References}

Amirin, Tatang M. (2011). Populasi dan Sampel Penelitian 3: Pengambilan Sampel dari Populasi Tak-terhingga dan Tak-jelas. tatangmanguny.wordpress.com

Badan Standardisasi Nasional. 1998. Sistem Analisa Bahaya dan Pengendalian Titik Kritis (HACCP) serta Pedoman Penerapannya. BSN. Jakarta.

Cole, R.E., Bacdayan, P., White, B.J. 1993. Quality, Participation, and Competitiveness. California Management Review. Spring.

Departemen Pertanian, 2007. Peraturan Menteri Pertanian Nomor: 273/Kpts/OT.160/4/2007. Departemen Pertanian. Jakarta.

Goetsch D.L dan Davis D.L. 2002. Introduction to Total Quality: Quality Management for Production, Process, and Service. Edisi Terjemahan. Alih Bahasa oleh Benyamin Molan. Manajemen Mutu Total: Manajemen Mutu untuk Produksi, Pengelolaan, dan Pelayanan. Jilid I. PT Prenhalindo. Jakarta.

International Organization for Standardization. 2000. ISO 9001:2000 -Quality Management System- Requirements. International Organization for Standardization. Geneve.

Iskandar, R.; M. Bintoro; dan E. Sugiartono, 2008. Penerapan Sistem Mutu Berkesinambungan pada Budidaya Edamame. Politeknik Negeri Jember, Jember.

Kolarik, William J. 1995. Creating Quality Concepts, Systems, Strategies, and Tools. McGraw-Hill International Editions. Singapore.

Kujala, J., P. Ullrank. 2004. Total Quality Management as a Cultural Phenomenon. uww.asq.org.

Munro-Faure, L., Munro-Faure, M. 1992. Implementing Total Quality Management. Longman Group UK Limited. London.

Novack, Janet L. 1995. The ISO 9000 Documentation Toolkit. Prentice Hall, Inc. Englewood Cliffs. New Jersey.

Robbins, S.P. 2003. Organizational Behavior. Tenth Edition. Prentice-Hall. Singapore

Soon, J.L., L.Manning, W.P.Davies, R.Baines, 2012. Fresh Produce-Associated Outbreaks: a Call for HACCP on Farms?, British Food Journal. 114(4):553-597

Tabe, Hamid Reza at. al., 2013. The Role of Implementation Total Quality Management System of Performance in SAIPA Group Companies. Kuwait Chapter of the Arabian Journal of Business and Management Review. 3 (4), 25-33.

USDA. 1999. Guidebook for the Preparation of HACCP Plans. USDA. Washington.

Wijaya, T. 2009. Analisis Structural Equation Modeling Menggunakan AMOS. Penerbit Universitas Atma Jaya, Yogyakarta.

Zulfifly, Muhammad Izzat;, et. al., 2010. An Investigative Study into the Hazard Analysis of Critical Control Point (HACCP) Implementation in the Small and Medium-Sized Food Manufacturing Enterprises (SMEs). Interdisciplinary Journal of Contemporary Research In Business. 1 (9), 46-69.

(http://myforesthouse.blogspot.com/2012/11/kedelai-jepang-menantang-ekspor.html). 